\title{
Religious Behavior of Indonesian Muslims as Responses to the Covid-19 Pandemic
}

\author{
Mohammad Hidayaturrahman ${ }^{1}$, Husamah Husamah ${ }^{2}$, \\ Sudarman Sudarman ${ }^{3}$, Fitri Yanti ${ }^{4}, \&$ \\ Ita Rahmania Kusumawati ${ }^{5}$ \\ ${ }^{1}$ Universitas Wiraraja, Madura, Indonesia \\ ${ }^{2}$ Universitas Muhammadiyah Malang, Indonesia \\ ${ }^{3}$ Universitas Islam Negeri Imam Bonjol, Padang, Indonesia \\ ${ }^{4}$ Universitas Islam Negeri Raden Intan, Lampung, Indonesia \\ ${ }^{5}$ Universitas Hasyim Asy'ari, Jombang, Indonesia \\ hidayaturrahman@wiraraja.ac.id
}

\begin{abstract}
Covid-19 has become a world pandemic, and Indonesia is among the worse cases. Problems that arise are faced by all parties, including religious elites as well as laypeople. This study was conducted to describe how Muslims in Indonesia responded to and tried to cope with the Covid-19 pandemic. The study uses descriptive qualitative methods to collect data by observation, in-depth interview by phone, and online searching documents. From the research conducted, Islamic mass organizations have a relatively similar opinion that limits religious activities supported by various religious arguments. As for laypeople's behavior, most are the same as mass organizations and Islamic leaders; very few have different behaviors. In anticipation of the virus spreading, most of them restricted religious activities in full by closing down the mosque and stopping public prayers. Few remained active as before the Covid-19 pandemic.
\end{abstract}

Keywords: Covid-19; Indonesian Muslims; mass organization; religious elite; religious behavior.

Abstrak: Covid-19 telah menjadi pandemi dunia, dan Indonesia termasuk di antara kasus terparah. Permasalahan yang muncul dihadapi semua pihak, baik elit agama maupun awam. Kajian ini dilakukan untuk mendeskripsikan bagaimana umat Islam di Indonesia menanggapi dan berusaha mengatasi pandemi Covid-19. Penelitian ini menggunakan metode deskriptif kualitatif dengan pengumpulan data melalui observasi, wawancara mendalam melalui telepon, dan pencarian dokumen secara online. Dari penelitian yang dilakukan, ormas Islam memiliki pendapat yang relatif sama yaitu membatasi kegiatan keagamaan yang didukung oleh berbagai dalil keagamaan. Adapun perilaku orang awam, sebagian besar sama dengan ormas dan tokoh Islam; sangat sedikit yang memiliki perilaku berbeda. Untuk mengantisipasi penyebaran virus, sebagian besar dari mereka membatasi kegiatan keagamaan secara penuh dengan menutup masjid dan menghentikan sholat umum. Beberapa tetap aktif seperti sebelum pandemi Covid-19.

Kata kunci: Covid-19; Muslim Indonesia; ormas Islam; tokoh Islam; perilaku keagamaan. 


\section{Introduction}

Covid-19 pandemic has made the world's conditions overwhelmed with big problems. ${ }^{1}$ Since it first appeared in Wuhan, China, in December 2019, this deadly virus has infected two million people in more than 200 countries globally and has a considerable impact ranging from psychological, social, to economical impact. ${ }^{2}$ The Covid-19 transmission process between humans is pretty fast, ${ }^{3}$ so the more people who interact and gather with infected people, the faster the transmission. ${ }^{4}$

Covid-19 is easily spread in a gathering place for people or crowded places, one of which is a place of worship. ${ }^{5}$ Many religious practices and rituals worldwide are vulnerable to becoming a media for the spread of Covid-19, including gathering in public spaces with many people, greetings by handshaking, and touching (considered-sacred) objects. ${ }^{6}$ As happened in South Korea, the coronavirus case first appeared in the middle of January 2020 in the Daegu area that hosts about 2.5 million people. One of Covid-19's scattering points in South Korea comes from the church in Daegu city, which is a continuous transmission chain, with $55 \%$ of cases related to the church cluster. ${ }^{7}$ In Zhejiang Province, China, there were also cases of hundreds of Buddhists who were worshiping in a temple. Covid-19 infected a 64-year-old female worshipper. The woman interacted with other worshippers at the temple, and in turn, some of them were finally got infected with Covid-19. ${ }^{8}$

A grand tabligh event held at the Sri Petaling Kuala Lumpur Malaysia mosque from February 28 to March 1, 2020, which was attended by more than 16,000 people from 26 countries, was also the center of the spread of the Covid-19 case. ${ }^{9}$ Furthermore, two religious seminars held in Bogor, West Java, Indonesia, became the source of the spread of Covid-19 in Indonesia. ${ }^{10}$

Many countries with a Muslim majority have been exposed to Covid-19, such as Iran, which then transmits to Afghanistan, Bahrain, Iraq, Kuwait, Lebanon, Oman, Pakistan, Qatar, Saudi Arabia, Egypt, and then United Arab Emirates. Global-scale transmission is vulnerable in Muslim countries by

${ }^{1}$ Debanjan Banerjee, "How COVID-19 Is Overwhelming Our Mental Health,” Nature India (India, March 2020), https://doi.org/10.1038/nindia.2020.46; David Adam, “Modelling the Pandemic: The Simulations Driving the World's Response to COVID-19," Nature 580, no. April (2020): 316-18, https://doi.org/10.1038/d41586-020-01003-6.

2 Wenjun Cao et al., "The Psychological Impact of the COVID-19 Epidemic on College Students in China," Psychiatry Research, 2020, 112934, https:/doi.org/10.1016/J.PSYCHRES.2020.112934; Sijia Li et al., "The Impact of Covid-19 Epidemic Declaration on Psychological Consequences: A Study on Active Weibo Users," International Journal of Environmental Research and Public Health 17, no. 6 (2020), https://doi.org/10.3390/ijerph17062032; Fitra Rizal and Haniatul Mukaromah, "Filantropi Islam Solusi Atas Masalah Kemiskinan Akibat Pandemi Covid-19," Al-Manhaj: Jurnal Hukum Dan Pranata Sosial Islam 3, no. 1 (2021): 35-66, https://doi.org/https://doi.org/10.37680/almanhaj.v3i1.631.

${ }^{3}$ Taisheng Li, Hongzhou Lu, and Wenhong Zhang, "Clinical Observation and Management of COVID-19 Patients.," Emerging Microbes \& Infections 9, no. 1 (2020): 687-90, https://doi.org/10.1080/22221751.2020.1741327.

${ }^{4}$ Muhammad Adnan Shereen et al., "COVID-19 Infection: Origin, Transmission, and Characteristics of Human Coronaviruses,” Journal of Advanced Research 24 (2020): 91-98, https://doi.org/10.1016/j.jare.2020.03.005.

5 Richard Florida, "What We Know about Density and Covid-19's Spread," CityLab, 2020, https://www.citylab.com/equity/2020/04/coronavirus-spread-map-city-urban-density-suburbs-rural-data/609394/; Marième Soumaré and Jules Crétois, "What Coronavirus Is Changing for Muslims," Theafricareport, 2020.

${ }^{6}$ World Health Organization, "Practical Considerations and Recommendations for Religious Leaders and Faith-Based Communities in the Context of COVID-19," Interim Guidance (Geneva, Switzerland, 2020).

${ }^{7}$ Eunha Shim et al., "Transmission Potential and Severity of COVID-19 in South Korea," International Journal of Infectious Diseases 93 (2020): 339-44, https://doi.org/10.1016/j.ijid.2020.03.031.

${ }^{8}$ Ye Shen and Changwei Li, "Airborne Transmission of COVID-19: Epidemiologic Evidence from Two Outbreak Investigations," no. April (2020), https://doi.org/10.13140/RG.2.2.36685.38881.

9 Rehia Sebayang, "Efek Tabligh Akbar, Kasus Covid-19 Di Malaysia Bertambah 190," CNBC Indonesia, March 2020; Clement Yong, "MOH Identifying 95 Singaporeans at Religious Gathering in Malaysia after Covid-19 Cases Confirmed," The Straits Times, March 2020.

${ }^{10}$ Aulia Adam, "Sebaran Maut COVID-19 Dua Seminar Di Bogor: Pemda Sigap Pusat Gagap,” Tirto.Id, 2020. 
religious tourism in these countries. ${ }^{11}$ As happened in Saudi Arabia, based on 2019 data, there are 7.5 million people who come from 180 countries around the world who perform the pilgrimage. ${ }^{12}$ Saudi Arabia became one of the countries whose population was infected and became the center of the possibility of being a Covid-19 transmission center of positive citizens from various countries in the world. $^{13}$

As one of the countries with the fourth most populated globally, Indonesia is very vulnerable to the pandemic, Covid-19. ${ }^{14}$ The government faces a difficult task to control the mobility of more than 240 million people, spread in 34 provinces and more than 500 cities consisting of islands that are separated from each other. Indonesia faces a crucial problem in dealing with Covid-19. In addition to geographical issues, Indonesia also faces problems with the heterogeneity of its population. Indonesian society is heterogony in terms of education, economic level, ethnicity, religion, culture, and political choices. So that the virus is estimated to quickly spreading. ${ }^{15}$

Indonesia is also the largest Muslim country in the world. The Muslim population, which is $80 \%$ of the total population of 240 million, makes an obviously large number. ${ }^{16}$ It also has consequences for many places of worship of Islam in Indonesia. Activities of worship for Muslims also have a greater frequency because of the five daily prayers usually held in a congregation (jama'ah) in a mosque. From the Indonesian Ministry of Religious Affairs' data, there are approximately 242,823 mosques and 269,076 mushallas (smaller mosques) throughout Indonesia. ${ }^{17}$ In Jakarta alone, there were at least 73 worshipers in a mosque infected with Covid-19; they were then isolated at a dedicated hospital to cure the pandemic case, Wisma Atlet, after undergoing a rapid test. ${ }^{18}$ The West Java Provincial Government also said that it would immediately conduct Covid-19 tests on 5000 kiai (Muslim leaders) in boarding schools spread in West Java.

Indonesian Muslims also have many religious traditions of festivities that enable Muslims to gather in their practice. Some examples are tahlilan that is a tradition of reading prayers and sentences of la ilaha illallah or verses of the Koran to commemorate and pray for the dead people. Tahlilan is usually performed during the first seven days of a person's death, on the 40th day, the 100th day, and the 1000 th day. ${ }^{19}$ Besides, there are also activities to commemorate the Prophet Muhammad's birthday

${ }^{11}$ WHO, “Syrian Arab Republic,” Definitions, no. 02 (2020), https://doi.org/10.32388/pzmfqv.

12 Jaffar A. Al-Tawfiq and Ziad A. Memish, "The Hajj 2019 Vaccine Requirements and Possible New Challenges," Journal of Epidemiology and Global Health 9, no. 3 (2019): 147-52, https://doi.org/10.2991/jegh.k.190705.001; Amir Vahdat and Jon Gambrell, "Saudi Officials Ban Pilgrimages to Mecca over COVID-19," Times, March 2020.

13 Shahul H. Ebrahim and Ziad A. Memish, "COVID-19: Preparing for Superspreader Potential among Umrah Pilgrims to Saudi Arabia,” The Lancet 395, no. 10227 (2020): e48, https://doi.org/10.1016/S0140-6736(20)30466-9.

14 Aruminingsih Sudjatma et al., "Of," Progress in Disaster Science, no. march (2020): 100091, https://doi.org/10.1016/j.pdisas.2020.100091; Deny Murdianto and Dwi Santoso, "Sosialisasi Persiapan Pembelajaran Di Masa New Normal Bagi Guru SMK Di Kota Tarakan,” Amalee: Indonesian Journal of Community Research and Engagement 2, no. 1 (2021): 53-62, https://doi.org/https://doi.org/10.37680/amalee.v2i1.624

${ }^{15}$ Natasa Adelayanti, "UGM Masters Predict the Spread of COVID-19 in Indonesia Stopped at the End of May 2020," 2020, https://www.ugm.ac.id/en/news/19219-ugm-masters-predict-the-spread-of-covid-19-in-indonesia-stopped-at-the-endof-may-2020.

${ }^{16}$ Martin Van Bruinessen, "Indonesian Muslims and Their Place in the Larger World of Islam," Indonesia Rising: The Repositioning of Asia's Third Giant, 2012, 117-40, https://doi.org/10.1355/9789814380416-013.

17 Sub Direktorat Kemasjidan Direktorat Urusan Agama Islam dan Pembinaan Syariah Direktorat Jenderal Bimas Islam Kementerian Agama Republik Indonesia, Buku Panduan Sistem Informasi Masjid (SIMAS) Kementerian Agama Republik Indonesia, 2015.

${ }^{18}$ Intan Prihatin, “73 Jemaah Masjid Jami Tamansari Kebon Jeruk Positif Corona Covid19 News Liputan6,” April 2020.

${ }^{19}$ Andi Warisno, “Tradisi Tahlilan Upaya Menyambung Silaturahmi,” Ri'ayah 02, no. 02 (2017): 69-79. 
(Maulid Nabi), the Isra' Mi'raj, the Hijriyah new year, and so forth. ${ }^{20}$ Indonesia also has Islamic mass organizations; among the largest are Nahdlatul Ulama, Muhammadiyah, Persatuan Islam, and AlIrsyad. $^{21}$

Religious behavior in the face of a pandemic is interesting to be studied. Religion has a vital role in dealing with all aspects of life. In any situation, religious activities become a manifestation of the existence of the community. ${ }^{22}$ The world has noted that religion contributes significantly to shaping humanity's history and civilization, ${ }^{23}$ including during the pandemic crisis. Previous research on the Ebola Pandemic found that religious beliefs and practices shape (positively and negatively) how to care for the sick, stigma patterns, and gender roles. ${ }^{24}$ Throughout the crisis, religious institutions have provided services including health, education, and social support.

However, not much research explicitly has been done to examine Muslims' behavior in Indonesia in dealing with a pandemic, let alone related to the Covid-19 pandemic. Therefore, this study was conducted to reveal how the laypeople Muslims' behavior, Islamic leaders, and Islamic mass organizations in Indonesia dealt with Covid-19. This study also analyzes how their behavior correlates with Skinner's Behavior Theory and Maslow's Needs Theory. This study can be a reference for policymakers to plan and fight the crisis effectively by increasing the stability of people's feelings. This study also has a strategic contribution globally, as Indonesian Muslims represent a large part of society. Besides, given that Indonesia is the largest Muslim population country in the world, its existence tends to be taken into account and is often a reference for world Muslims.

\section{Method}

This study uses descriptive qualitative methods, which describe how the Indonesian Muslims' behavior in responding to the Covid-19 pandemic. Data collection is done by observing mosque activities in the Capital City of Jakarta, West Sumatra, Jambi, and Madura. In addition, it also carried out in-depth interviews by interviewing the mosque officials who closed the mosque to break the chain of transmission of Covid-19. We also searched documents online on the Indonesian Islamic mass organization's official website and from releases published on the mass media. The documents collected were in the form of decrees, releases, and official press releases of the foremost Islamic mass organizations in Indonesia, namely the Indonesian Ulema Council (or Majelis Ulama Indonesia) as a council of all Islamic mass organizations, Nahdlatul Ulama, Muhammadiyah, Persatuan Islam, and AlIrsyad. The certificate that has become a press release is then combined with the leaders' statements (or religious elites) quoted by various online media. Data on Islamic leaders' behavior and actions relating to the Covid-19 pandemic were collected through online media and social media, such as YouTube, Twitter, Instagram, and Facebook, which originated from each character's official accounts, the media that made the figures as resource persons. This kind of latest data on Indonesian Muslims' general

\footnotetext{
${ }^{20}$ Angelina Rianti et al., “Ketupat as Traditional Food of Indonesian Culture,” Journal of Ethnic Foods 5, no. 1 (2018): 4-9, https://doi.org/10.1016/j.jef.2018.01.001.

${ }^{21}$ Risti Permani, "The Presence of Religious Organisations, Religious Attendance and Earnings: Evidence from Indonesia," Journal of Socio-Economics 40, no. 3 (2011): 247-58, https://doi.org/10.1016/j.socec.2011.01.006.

${ }^{22}$ Asrudin Azwar and Musa Maliki, "Covid-19, Agama, Dan Sains," GEOTIMES, 2020.

${ }^{23}$ Michael B. Horn, “COVID-19's Long-Term Impacts on Education in 2020 and Beyond,” EdSurge, March 2020; Agus Setyawan, "Dakwah Yang Menyelamatkan: Memaknai Ulang Hakikat Dan Tujuan Da'wah Islamiyah," Al-Adabiya: Jurnal Kebudayaan Dan Keagamaan 15, no. 02 (2020): 189-99, https://doi.org/https://doi.org/10.37680/adabiya.v15i02.487.

${ }^{24}$ Katherine Marshall and Sally Smith, "Religion and Ebola: Learning from Experience," The Lancet 386, no. 10005 (2015): e24-25, https://doi.org/10.1016/S0140-6736(15)61082-0.
} 
behavior is obtained from online media that specifically report on Muslim activities relevant to implementing specific religious activities/rituals, such as Friday prayers, praying in congregation in mosques, recitation, holidays, and other religious activities. The data collected and described were then analyzed using Skinner's behavior theory ${ }^{25}$ and Maslow's theory of needs ${ }^{26}$. Analysis of behavior theory can also be applied to analyze individuals' and groups' behavior, including institutional structures. ${ }^{27}$

\section{Result and Discussion}

\section{Religious Mass Organizations' Behavior}

Behavior is a response that arises due to the stimulus. Responding to the Covid-19 pandemic, the Majelis Ulama Indonesia specifically made a fatwa relating to Covid-19, on a letter number 14, dated March 16, 2020, which contained the obligation to isolate oneself who had been exposed to Covid-19. It is even haram (illicit) for the infected patient to perform sunnah (additional, not obligatory) worship, which caused other people to be exposed, such as Tarawih and Eid al-Fitr prayer. When the Covid-19 pandemic is out of control and threatens lives' safety, Friday prayers should not be held at the mosque and replaced with Dhuhur prayers at home. Likewise, other religious activities that involve a crowd of people are totally prohibited - instructed to ensure that there is no direct physical contact, such as shaking hands, hugging and kissing hands, and diligently washing hands with antiseptics soap.

Another organization, Nahdlatul Ulama, through a circular letter numbered 3953/C.I.034.04.3030, signed by Rais 'Aam KH Miftachul Akhyar, Khatib' Aam KH Yahya Cholil Staquf, PBNU Chairperson KH Said Aqil Siroj, and Secretary General H. A Helmy Faishal Zaini, dated April 3, 2020, issued a decision to break the chain of distribution of Covid-19. One way is to avoid the activities of meeting and gathering Muslims in large numbers. The implementation of worship such as Tarawih prayer, which is usually done in a congregation (jama'ah) in mosques and prayer rooms, is enough to be held in own homes during the pandemic period. Likewise, the Eid prayer during the Covid-19 pandemic did not take place at the mosque. The hospitality activities on the Eid al-Fitr 1441 Hijriyya (2020) must refer to the provisions and policies of social restrictions and maintain physical distance determined by the government.

Muhammadiyah, the second-largest Islamic mass organization in Indonesia, also responded to the Covid-19 pandemic by issuing a circular letter regarding guidance for worship in Covid-19 emergency conditions, number 02/EDR/I.0/E, issued March 24, 2020. which required physical and social distance. The five daily prayers, which are usually held at the mosque/mushalla are now to be held in own homes. Likewise, the implementation of Friday, Tarawih, and Witir prayers on the month of Ramadhan experienced changes. Muhammadiyah also excludes religious lectures, congregational meetings, and

${ }^{25}$ George Graham, "Behaviorism," in The Stanford Encyclopedia of Philosophy (Stanford University Press, 2019); A. Charles Catania, "The Operant Behaviorism of B. F. Skinner," Behavioral and Brain Sciences 7, no. 4 (1984): 473-75, https://doi.org/10.1017/S0140525X00026728; Murray J. Goddard, "B. F. Skinner's Science and Human Behavior: Some Further Consequences," Review of General Psychology 21, no. 3 (2017): 276-80, https://doi.org/10.1037/gpr0000117.

${ }^{26}$ Glenn Geher, “Corona Viewed from Maslow's Hierarchy of Needs,” Psychology Today, 2020; Goddard, "B. F. Skinner's Science and Human Behavior: Some Further Consequences."

27 Kevin N. Laland and Luke Rendell, "Social Learning: Theory," Encyclopedia of Animal Behavior, 2019, https://doi.org/10.1016/B978-0-12-813251-7.00057-2; Jake Morris et al., "Theories and Models of Behaviour and Behaviour Change," Forestry, Sustainable Behaviours and Behaviour Change: Theories, 2012, 1-27. 
i'tikaf activities in mosques. Eid Al-Fitr Prayer - because its original law is sunnah - does not need to be held.

Persatuan Islam also issued a circular letter relating to the Hisbah View on the impact of corona according to Islamic law, which was published on March 18, 2020. When the Covid-19 pandemic is out of control, the Friday prayer can be replaced by the Dhuhur prayer, especially when it could not be carried out in safety measurement. The same thing was stated by the mass organization Al-Irsyad, through Fatwa of the Al-Irsyad Fatwa Council, No: 026/DFPA/VII/1441, dated March 18, 2020, which allowed Muslims not to pray in congregation in the mosque even though they felt well. For areas in active Covid-19 transmissions, citizens are encouraged to isolate themselves at home, and Friday prayer obligations at the mosque can be aborted and replaced with Dhuhur prayers at home.

\section{Religious Elites' Behavior}

In addition to Islamic mass organizations, certain behaviors were also expressed by Islamic leaders in Indonesia. One of them, KH. Abdullah Gymnastiar, the caregiver at Daarut Tauhid Islamic Boarding School in Bandung, West Java, who directly went to the field, met with the community, conducted socialization and awareness on the dangers of Covid-19 and its handling efforts. According to him, religion exists to bring benefit and avoid harm. Citing the Sharia law, he stated that "Eliminating harm is more important than bringing benefit. In the current situation, we get the same reward as going to the mosque, even though we pray at home. Even the rewards increase because we do no harm against others". 28

Another Islamic leader who has a stance on the spread of Covid-19 is Ustadz Abdus Shomad. He stated that "The Prophet Muhammad taught us: if you hear there is an epidemic in an area, do not you dare to come to that place. Furthermore, if you are already in an area where there is an epidemic, then do not leave the area. Besides, the Prophet Muhammad also ruled if you meet people with infectious diseases, then run away like people running away from the pursuit of a lion. At the time of the Caliph Umar, there was a plagued area, then the Caliph Umar was invited to move from that place to a sterilized place from the plague that was still empty, not occupied by humans. Keeping a distance among others by not touching or shaking hands in the current situation is practicing the sunnah. So we have to keep our distance, not crowding, and even I do not hold a public recitation, let alone a grand tabligh in a current situation. In Egypt, which has fewer victims than Indonesia, the ulama has given a fatwa aborting the obligation to pray on Friday and pray five times at the mosque. So, Indonesia is not wrong if doing so." 29

Habib M. Quraish Shihab, the founder of the Center for the Study of the Qur'an (Pusat Studi alQur'an) in Jakarta, also stated, "Responding to the Corona disaster which has engulfed the world and also regarding good and innocent people. This is a disaster that is a test and warning from God for the human race, who today are proud and feel able to do everything. Good people who die because of corona will be rewarded by Allah, as conveyed by the Prophet Muhammad, that those who die due to a tha'un, an illness that was plagued during the time of the Prophet Muhammad or his companions, they are regarded as syahid. It is the same as those of martyrs who died in holy battle defending the truth.

\footnotetext{
${ }^{28}$ CNN Indonesia TV Channel, "KH Abdullah Gymnastiar Aired on March 26, 2020.,” 2020.

${ }^{29}$ Ustadz Abdul Somad Official YouTube Channel, "BAGAIMANA SIKAP UAS TERHADAP SITUASI WABAH CORONA? | Ustadz Prof. Abdul Somad, Lc., MA., Ph.D.', 19 Mar. 2020," n.d., www.youtube.com/watch?v=X8xQrSBQtL8.
} 
The virus can also be named as demons. One of them is a story in the Koran that tells the Prophet Ayyub who said, 'the devil has befallen me with a disease which afflicts and torments me.' The Prophet Muhammad also stated that tha'un was the devil's work, the work of the hidden genie. Because it is a demon we must fight, we must avoid, and we must fight."30

\section{Discussion}

Responses given by the Muslims in general in Indonesia can suppress the spread of Covid-19. It can be seen from comparing the conditions at which the fatwa was valid and was implemented and no longer implemented. First, when the fatwa was implemented, the number of Covid-19 sufferers in Indonesia was around 32,033 positive cases. Meanwhile, at the end of January 2021, positive cases in Indonesia reached 951,651 people.

Table 1. Comparison of Covid-19 Cases in Indonesia When Fatwa Enacted Closing Mosques and Musholla

$\begin{array}{ccc}\text { Location } & \text { The End of the Fatwa Takes Place } & \text { Fatwa Not Implemented } \\ 8 \text { June } 2020 & \text { January 21, 2021 }\end{array}$

1 The number of new cases was

847 people

2 The number of positive cases was 32,033

$$
\text { people }
$$

3 The number of patients who died was

$$
1,883 \text { people }
$$

The number of new cases is

$$
11,703 \text { people }
$$

The number of positive cases was

$$
\text { 951,651 people }
$$

The total number of patients died was 27,203

people

(Source: Researchers Processed from Various Sources, 2021).

As for Muslims' behavior in Indonesia facing Covid-19, the attitude generally appeared to be in accordance with what was conveyed by Islamic mass organizations and Islamic leaders. It can be seen from the closure of major mosques. The mosques also do not hold Friday prayers, pray in a congregation for five times, nor do the regular public festivities. A small portion of Muslims behaves differently by opening mosques for congregational prayers and Friday prayers, especially those in suburban, rural, and remote areas. However, they also no longer hold routine festivities as were usually done before the pandemic. The Indonesian Muslims also avoided as for relating to religious routines such as grand tabligh (public sermon), tahlilan, tasyakuran, and others. They prefer to maintain social contact. However, some habits still have not been disciplined about maintaining physical contact; they keep shaking hands when they meet each other, even though they are accustomed to wearing masks and washing the hands routinely.

The Behavior Theory can be used to analyze the behavior of Muslims, Islamic leaders, and Islamic mass organizations in Indonesia in relation to Covid-19. According to Skinner, behavior arises as a response to a stimulus originating from external factors. In Skinner's Theory of Behavior, the same

${ }^{30}$ Najwa Shihab YouTube Channel, “"Benarkah Corona Tentara Allah?: Shihab \& Shihab.', 22 Mar. 2020,” 2020, n.d., youtu.be/gtd4xR_YjY4. 
response will arise if the stimulus is also the same. ${ }^{31}$ The behavior of lay Muslims, Islamic leaders, and Islamic mass organizations in Indonesia is clearly a response that emerged after the Covid-19 pandemic. Their behavior is then manifested in the practice of religious rituals or daily worship. The behavior of Friday prayers together at the mosque, praying in congregation five times at the mosque/mushalla, opening mosques to carry out various religious activities, and festivities were drastically changed by the existence of the Covid-19 pandemic.

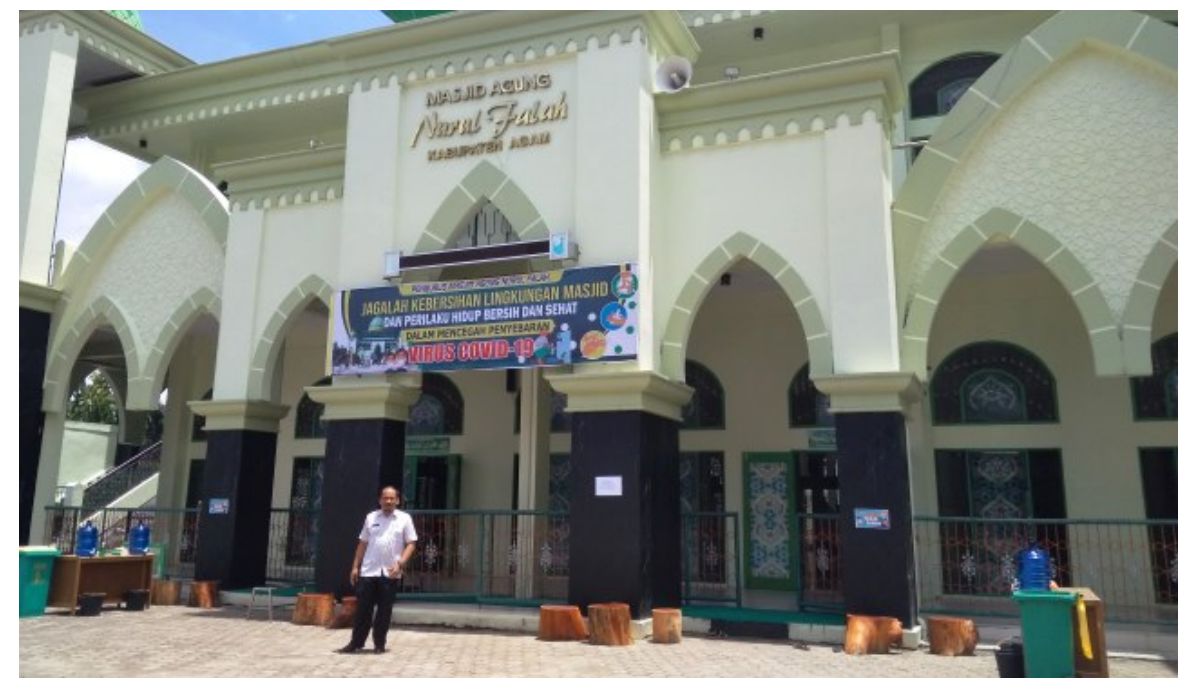

Figure 1. Nurul Falah Mosque in Agam, West Sumatra, temporarily closed during pandemic Covid-19

(Source: Researcher Private document, 2020)

Syafirman, takmir of Nurul Falah Mosque, Agam West Sumatra (Figure 1), said on a phone interview on April 15, 2020, that based on the MUI's edict and the West Sumatra Governor's Circular, so that mosques in areas in the red zone did not carry out congregational and Friday prayers, the committee decided to stop prayer congregation and Friday prayers at this mosque.

Meanwhile, according to Ustadz Taufiqurrahman, takmir of Baiturrahman Mosque, North Jakarta, on a phone interview on March 20,2020, his party agreed to temporarily close Friday prayer activities, praying in a congregation for five times, including recitation, after learning that Jakarta was part of a pandemic Covid-19. "Avoiding harm is better than taking advantage is the fiqh rules taught by the ulama. We never know which person among us exposed to Covid-19 who came to the mosque, then joined the prayer with us, and those who worshiped at the mosque then returned to their homes and transmitted Covid-19 to families at home, including parents and children. So we chose to temporarily refrain from holding regular worship activities at our mosque."

The similar policy was also conveyed by KH. Ad-Dailamy, chairman of the Abu Hurairah Mosque's board of takmir, in Sapeken, a small island of Madura, East Java. They deliberately negate the prayer activities in a congregation on the grounds of avoiding harm that occurs if worshipers exposed to Covid-19 come to the mosque and transmit it to other worshipers, even more so with the condition of health facilities on Sapeken Island that are inadequate to deal with Covid-19 patients. "If

${ }^{31}$ Ray L. Birdwhistell, : “: Science and Human Behavior . B. F. Skinner.”, American Anthropologist 56, no. 5 (1954): 898-99, https://doi.org/10.1525/aa.1954.56.5.02a00210; E. A. Vargas, “B. F. Skinner's Theory of Behavior," European Journal of Behavior Analysis 18, no. 1 (2017): 2-38, https://doi.org/10.1080/15021149.2015.1065640. 
there are residents exposed to Covid-19 then come to the mosque, and interact with other worshipers, then when other worshipers are exposed, residents of one island may be exposed eventually. While in our island Sapeken there are no hospitals, no lung specialist doctors, no health facilities that allow people exposed to Covid-19 to be treated. There is only Puskemas, and only residents can be taken to Bali or to Surabaya, while the distance to Bali and Surabaya is quite far, it can take three days to arrive, what will be taken there. We better prevent it.", said KH. Ad-Dailamy on a phone interview on April 5, 2020 .

The mosque officers even posted a large banner in front of the mosque informing the rule should be obeyed by anyone who visits the mosque (Figure 2). The banner shows that people should keep the distance from others, avoid physical contact, and any other measurements considered as Covid-19 protocol. Besides pausing the congregation activities, the banner publication is one of the institutional efforts in coping with the pandemic.

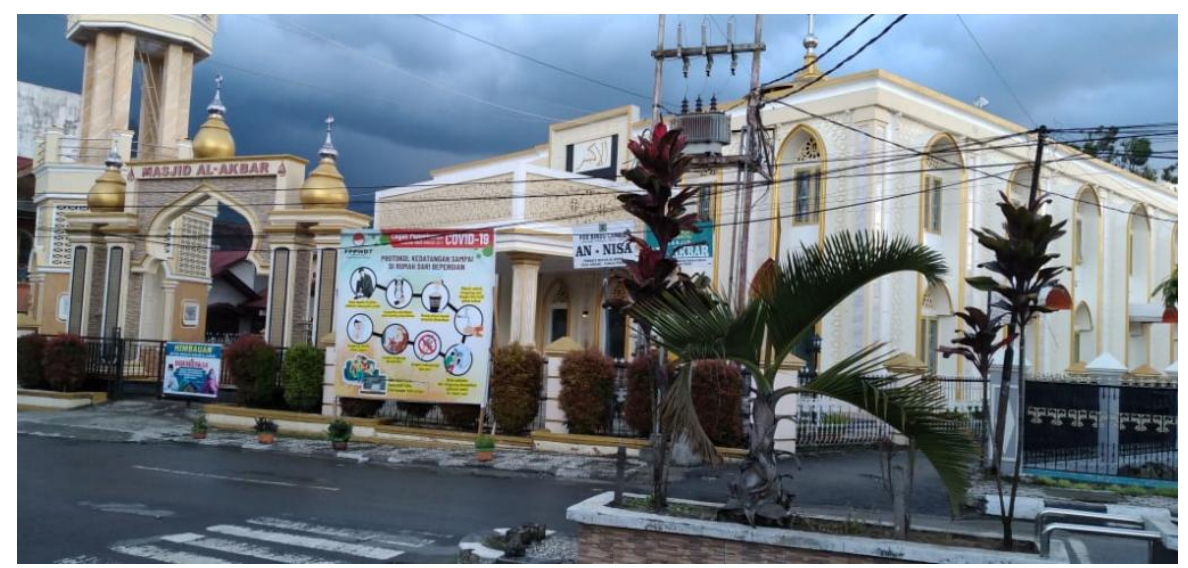

Figure 2. Al-Akbar Mosque in Kerinci, Jambi temporarily closed during pandemic Covid-19

(Source: Researcher Private document, 2020)

Behavior arises as a response to avoid undesirable things and to get something desired, ${ }^{32}$ also an attempt to save themselves, avoid danger, and in the end, is survival. ${ }^{33}$ In addition to encouraging the avoidance of undesirable things, in the form of illness and death, and to get the desirable thing, namely healthy living, the behavior of Islamic mass organizations, Islamic leaders, and Muslims in Indonesia, in general, are also driven by a belief in the truth of the teachings of the religion of Islam. At this stage, the religious doctrine adopted is the response that has been taught and received, in the form of information obtained through the Koran and Hadith. These arguments were first used as a basis for consideration to make a decree or take a decision regarding religious rituals, before consideration of health factors and the threat of a pandemic. This is in line with, most Muslims, see Islam as a way of life and follow Islamic instructions in all their daily practices.

The Behavioral Theory is relevant to describe the behavior of Indonesian Muslims, but it is not enough to analyze it, so it must also be juxtaposed with the Theory of Needs proposed by Abraham

\footnotetext{
32 Jack Mearns, “The Social Learning Theory of Julian B. Rotter,” American Psychologist 37, no. 4 (1982): 396-410, https://doi.org/10.1037//0003-066X.37.4.396.

${ }^{33}$ Gerald P. Koocher and Patricia Keith-Spiegel, “'What Should I Do?’ Ethical Risks, Making Decisions, and Taking Action," Courses for Mental Health Professionals, 2019; Mark R. Leary, "Emotional Responses to Interpersonal Rejection," Dialogues in Clinical Neuroscience 17, no. 4 (2015): 435- 41.
} 
Maslow. Maslow said there are five human needs: physical needs, security, affection, recognition, and self-actualization. The five needs are met in stages, starting from physical needs. ${ }^{34}$ In reviewing the Theory of Needs, then after getting a sense of security, then religious leaders, Muslims, and Islamic mass organizations in Indonesia actualize their religion's teachings. They did not come to the Koran recitation, closed the mosque, did not hold the five daily prayers at the mosque, and did not hold the Friday prayer activity is the need for the actualization of religious teachings in response to the Covid-19 pandemic. In Islam, self-actualization to implement religious teachings means meeting the need to follow religious teachings, and because following religious teachings, are rewarded in the hereafter. ${ }^{35}$

In Maslow's view, needs are the main force that sustains the behavior of people and society. Needs directly influence thinking and acting so that what is done by individuals or groups is basically based on needs. ${ }^{36}$ Human needs basically drive the behavior that arises. Fulfilling the highest needs is self-actualization. ${ }^{37}$ If humans do something based on self-activation, then it really is at the peak of their needs. ${ }^{38}$

The behavior that appears in the lay people, figures, and mass organizations of Islam in Indonesia is clearly linear with Abraham Maslow's Theory of Needs. It is just that, if Maslow states that needs are met in stages starting from physical needs, and so on the behavior of the people, leaders, and Islamic mass organizations in Indonesia, the Theory of Needs is not done in stages, but carried out simultaneously. On the one hand, the people and leaders want to survive the illness and death caused by Covid-19, but at the same time, they do so because they actualize themselves to carry out religious teachings that are believed to be true. On that basis, they did it and believed that by doing so they not only avoided Covid-19, but also practiced what was supposed to be done through the religious perspective. In turn, they were going to be rewarded with merit, and the ultimate reward will be heaven. It is precisely to get a sense of security of pain and death; they actualize themselves by carrying out religious orders, as stated in a circular of mass organizations and opinions of religious leaders conveyed to the public.

\section{Conclusion}

The behavior of Muslims, Islamic leaders, and Islamic mass organizations in Indonesia in response to Covid-19 is relatively uniform. They try to limit the distribution by breaking the chains. Breaking the contagion chain also changed the behavior of their religious activities by restricting congregational activities in the mosque, both for fardhu, compulsory worships, and sunnah, additional ones. In

34 Stoyan Stoyanov, "A Theory of Human Motivation," A Theory of Human Motivation, 2017, 1-87, https://doi.org/10.4324/9781912282517; Saul McLeod, “Maslow's Hierarchy of Needs,” Simply Psychology, 2020.

${ }^{35}$ Oktaful Ghofur, "Konsep Aktualisasi Diri Abraham H. Maslow Dan Korelasinya Dalam Membentuk Kepribadian (Analisis Bimbingan Dan Konseling Islam)" (Fakultas Dakwah Institut Agama Islam Negeri Walisongo Semarang, 2006).

${ }^{36}$ Wei Ta Fang et al., "Normative Beliefs, Attitudes, and Social Norms: People Reduce Waste as an Index of Social Relationships When Spending Leisure Time," Sustainability (Switzerland) 9, no. $10 \quad$ (2017), https://doi.org/10.3390/su9101696; Alma Acevedo, “A Personalistic Appraisal of Maslow's Needs Theory of Motivation: From 'Humanistic' Psychology to Integral Humanism,” Journal of Business Ethics 148, no. 4 (2018): 741-63, https://doi.org/10.1007/s10551-015-2970-0.

37 Andreas Komninos, "Self-Actualization: Maslow's Hierarchy of Needs," Interaction Design Foundation, 2020; Douglads Kenrick, "Renovating the Pyramid of Built upon Ancient Foundations," Perspect Psychol Sci 5, no. 3 (2011): 292314, https://doi.org/10.1177/1745691610369469.Renovating; Beata Souders, "Motivation and What Really Drives Human Behavior," Positive Psychology, 2020.

38 O. Venugopalan, "Maslow's Theory of Motivation: Its Relevance and Application among Non-Managerial Employees of Selected Public and Private Sector Undertakings in Kerala," Education + Training, 2007, 37-60. 
behavior theory, this is the response given to Covid-19. The behavior is in line with Maslow's Theory of Needs that needs drive behavior. In this case, between fulfilling the need for security and fulfilling the need for self-actualization to carry out religious teachings to practice the good deeds.

\section{References}

Acevedo, Alma. "A Personalistic Appraisal of Maslow's Needs Theory of Motivation: From 'Humanistic' Psychology to Integral Humanism." Journal of Business Ethics 148, no. 4 (2018): 741-63. https://doi.org/10.1007/s10551-015-2970-0.

Adam, Aulia. “Sebaran Maut COVID-19 Dua Seminar Di Bogor: Pemda Sigap Pusat Gagap.” Tirto.Id, 2020 .

Adam, David. "Modelling the Pandemic: The Simulations Driving the World's Response to COVID19." Nature 580, no. April (2020): 316-18. https://doi.org/10.1038/d41586-020-01003-6.

Adelayanti, Natasa. "UGM Masters Predict the Spread of COVID-19 in Indonesia Stopped at the End of May 2020," 2020. https://www.ugm.ac.id/en/news/19219-ugm-masters-predict-the-spread-ofcovid-19-in-indonesia-stopped-at-the-end-of-may-2020.

Al-Tawfiq, Jaffar A., and Ziad A. Memish. "The Hajj 2019 Vaccine Requirements and Possible New Challenges." Journal of Epidemiology and Global Health 9, no. 3 (2019): 147-52. https://doi.org/10.2991/jegh.k.190705.001.

Azwar, Asrudin, and Musa Maliki. “Covid-19, Agama, Dan Sains.” GEOTIMES, 2020.

Banerjee, Debanjan. "How COVID-19 Is Overwhelming Our Mental Health." Nature India. India, March 2020. https://doi.org/10.1038/nindia.2020.46.

Birdwhistell, Ray L. : “: Science and Human Behavior . B. F. Skinner.” American Anthropologist 56, no. 5 (1954): 898-99. https://doi.org/10.1525/aa.1954.56.5.02a00210.

Bruinessen, Martin Van. "Indonesian Muslims and Their Place in the Larger World of Islam." Indonesia Rising: The Repositioning of Asia's Third Giant, 2012, 117-40. https://doi.org/10.1355/9789814380416-013.

Cao, Wenjun, Ziwei Fang, Guoqiang Hou, Mei Han, Xinrong Xu, Jiaxin Dong, and Jianzhong Zheng. "The Psychological Impact of the COVID-19 Epidemic on College Students in China." Psychiatry Research, 2020, 112934. https://doi.org/10.1016/J.PSYCHRES.2020.112934.

Catania, A. Charles. "The Operant Behaviorism of B. F. Skinner." Behavioral and Brain Sciences 7, no. 4 (1984): 473-75. https://doi.org/10.1017/S0140525X00026728.

CNN Indonesia TV Channel. “KH Abdullah Gymnastiar Aired on March 26, 2020.,” 2020.

Ebrahim, Shahul H., and Ziad A. Memish. "COVID-19: Preparing for Superspreader Potential among Umrah Pilgrims to Saudi Arabia." The Lancet 395, no. 10227 (2020): e48. https://doi.org/10.1016/S0140-6736(20)30466-9.

Fang, Wei Ta, Eric Ng, Ching Ming Wang, and Ming Lin Hsu. "Normative Beliefs, Attitudes, and Social Norms: People Reduce Waste as an Index of Social Relationships When Spending Leisure Time.” Sustainability (Switzerland) 9, no. 10 (2017). https://doi.org/10.3390/su9101696.

Florida, Richard. "What We Know about Density and Covid-19's Spread." CityLab, 2020. https://www.citylab.com/equity/2020/04/coronavirus-spread-map-city-urban-density-suburbsrural-data/609394/.

Geher, Glenn. “Corona Viewed from Maslow’s Hierarchy of Needs.” Psychology Today, 2020. 
Ghofur, Oktaful. "Konsep Aktualisasi Diri Abraham H. Maslow Dan Korelasinya Dalam Membentuk Kepribadian (Analisis Bimbingan Dan Konseling Islam).” Fakultas Dakwah Institut Agama Islam Negeri Walisongo Semarang, 2006.

Goddard, Murray J. "B. F. Skinner's Science and Human Behavior: Some Further Consequences." Review of General Psychology 21, no. 3 (2017): 276-80. https://doi.org/10.1037/gpr0000117.

Graham, George. "Behaviorism." In The Stanford Encyclopedia of Philosophy. Stanford University Press, 2019.

Horn, Michael B. "COVID-19's Long-Term Impacts on Education in 2020 and Beyond." EdSurge. March 2020.

Kenrick, Douglads. "Renovating the Pyramid of Built upon Ancient Foundations." Perspect Psychol Sci 5, no. 3 (2011): 292-314. https://doi.org/10.1177/1745691610369469.Renovating.

Komninos, Andreas. "Self-Actualization: Maslow's Hierarchy of Needs." Interaction Design Foundation, 2020.

Koocher, Gerald P., and Patricia Keith-Spiegel. “'What Should I Do?' Ethical Risks, Making Decisions, and Taking Action.” Courses for Mental Health Professionals, 2019.

Laland, Kevin N., and Luke Rendell. "Social Learning: Theory." Encyclopedia of Animal Behavior, 2019. https://doi.org/10.1016/B978-0-12-813251-7.00057-2.

Leary, Mark R. "Emotional Responses to Interpersonal Rejection." Dialogues in Clinical Neuroscience 17, no. 4 (2015): 435-41.

Li, Sijia, Yilin Wang, Jia Xue, Nan Zhao, and Tingshao Zhu. "The Impact of Covid-19 Epidemic Declaration on Psychological Consequences: A Study on Active Weibo Users." International Journal of Environmental Research and Public Health 17, no. 6 (2020). https://doi.org/10.3390/ijerph17062032.

Li, Taisheng, Hongzhou Lu, and Wenhong Zhang. "Clinical Observation and Management of COVID19 Patients." Emerging Microbes \& Infections 9, no. 1 (2020): 687-90. https://doi.org/10.1080/22221751.2020.1741327.

Marshall, Katherine, and Sally Smith. "Religion and Ebola: Learning from Experience." The Lancet 386, no. 10005 (2015): e24-25. https://doi.org/10.1016/S0140-6736(15)61082-0.

McLeod, Saul. “Maslow's Hierarchy of Needs.” Simply Psychology, 2020.

Mearns, Jack. "The Social Learning Theory of Julian B. Rotter." American Psychologist 37, no. 4 (1982): 396-410. https://doi.org/10.1037//0003-066X.37.4.396.

Morris, Jake, Mariella Marzano, Norman Dandy, and Liz O'Brien. "Theories and Models of Behaviour and Behaviour Change." Forestry, Sustainable Behaviours and Behaviour Change: Theories, 2012, 1-27.

Murdianto, Deny, and Dwi Santoso. "Sosialisasi Persiapan Pembelajaran Di Masa New Normal Bagi Guru SMK Di Kota Tarakan.” Amalee: Indonesian Journal of Community Research and Engagement 2, no. 1 (2021): 53-62. https://doi.org/https://doi.org/10.37680/amalee.v2i1.624.

Najwa Shihab YouTube Channel. "'Benarkah Corona Tentara Allah?: Shihab \& Shihab.', 22 Mar. 2020.”2020, n.d. youtu.be/gtd4xR_YjY4.

Permani, Risti. "The Presence of Religious Organisations, Religious Attendance and Earnings: Evidence from Indonesia." Journal of Socio-Economics 40, no. 3 (2011): 247-58. https://doi.org/10.1016/j.socec.2011.01.006.

Prihatin, Intan. "73 Jemaah Masjid Jami Tamansari Kebon Jeruk Positif Corona Covid19 News Liputan6," April 2020. 
Rianti, Angelina, Agnes E. Novenia, Alvin Christopher, Devi Lestari, and Elfa K. Parassih. "Ketupat as Traditional Food of Indonesian Culture." Journal of Ethnic Foods 5, no. 1 (2018): 4-9. https://doi.org/10.1016/j.jef.2018.01.001.

Rizal, Fitra, and Haniatul Mukaromah. "Filantropi Islam Solusi Atas Masalah Kemiskinan Akibat Pandemi Covid-19." Al-Manhaj: Jurnal Hukum Dan Pranata Sosial Islam 3, no. 1 (2021): 35-66. https://doi.org/https://doi.org/10.37680/almanhaj.v3i1.631.

Sebayang, Rehia. "Efek Tabligh Akbar, Kasus Covid-19 Di Malaysia Bertambah 190." CNBC Indonesia. March 2020.

Setyawan, Agus. "Dakwah Yang Menyelamatkan: Memaknai Ulang Hakikat Dan Tujuan Da'wah Islamiyah.” Al-Adabiya: Jurnal Kebudayaan Dan Keagamaan 15, no. 02 (2020): 189-99. https://doi.org/https://doi.org/10.37680/adabiya.v15i02.487.

Shen, Ye, and Changwei Li. "Airborne Transmission of COVID-19: Epidemiologic Evidence from Two Outbreak Investigations,” no. April (2020). https://doi.org/10.13140/RG.2.2.36685.38881.

Shereen, Muhammad Adnan, Suliman Khan, Abeer Kazmi, Nadia Bashir, and Rabeea Siddique. "COVID-19 Infection: Origin, Transmission, and Characteristics of Human Coronaviruses." Journal of Advanced Research 24 (2020): 91-98. https://doi.org/10.1016/j.jare.2020.03.005.

Shim, Eunha, Amna Tariq, Wongyeong Choi, Yiseul Lee, and Gerardo Chowell. "Transmission Potential and Severity of COVID-19 in South Korea." International Journal of Infectious Diseases 93 (2020): 339-44. https://doi.org/10.1016/j.ijid.2020.03.031.

Souders, Beata. "Motivation and What Really Drives Human Behavior." Positive Psychology, 2020.

Soumaré, Marième, and Jules Crétois. "What Coronavirus Is Changing for Muslims." Theafricareport, 2020.

Stoyanov, Stoyan. "A Theory of Human Motivation." A Theory of Human Motivation, 2017, 1-87. https://doi.org/10.4324/9781912282517.

Sub Direktorat Kemasjidan Direktorat Urusan Agama Islam dan Pembinaan Syariah Direktorat Jenderal Bimas Islam Kementerian Agama Republik Indonesia. Buku Panduan Sistem Informasi Masjid (SIMAS) Kementerian Agama Republik Indonesia, 2015.

Sudjatma, Aruminingsih, Mochamad Indrawan, Muhammad Sabaruddin Sinapoy, Irina Rafliana, Susanti Djalante, Lalu Adi Gunawan, Rafael Anindito, and I Gusti Ayu Surtiari. "Of." Progress in Disaster Science, no. march (2020): 100091. https://doi.org/10.1016/j.pdisas.2020.100091.

Ustadz Abdul Somad Official YouTube Channel. "BAGAIMANA SIKAP UAS TERHADAP SITUASI WABAH CORONA ? | Ustadz Prof. Abdul Somad, Lc., MA., Ph.D.', 19 Mar. 2020," n.d. www.youtube.com/watch?v=X8xQrSBQtL8.

Vahdat, Amir, and Jon Gambrell. "Saudi Officials Ban Pilgrimages to Mecca over COVID-19." Times. March 2020.

Vargas, E. A. “B. F. Skinner's Theory of Behavior.” European Journal of Behavior Analysis 18, no. 1 (2017): 2-38. https://doi.org/10.1080/15021149.2015.1065640.

Venugopalan, O. "Maslow's Theory of Motivation: Its Relevance and Application among NonManagerial Employees of Selected Public and Private Sector Undertakings in Kerala." Education + Training, 2007, 37-60.

Warisno, Andi. “Tradisi Tahlilan Upaya Menyambung Silaturahmi.” Ri'ayah 02, no. 02 (2017): 69-79.

WHO. “Syrian Arab Republic.” Definitions, no. 02 (2020). https://doi.org/10.32388/pzmfqv.

World Health Organization. "Practical Considerations and Recommendations for Religious Leaders and 
Religious Behavior of Indonesian Muslims as Responses to the Covid-19 Pandemic

Mohammad Hidayaturrahman, Husamah, Sudarman, Fitri Yanti, \& Ita Rahmania Kusumawati

Faith-Based Communities in the Context of COVID-19." Interim Guidance. Geneva, Switzerland, 2020.

Yong, Clement. "MOH Identifying 95 Singaporeans at Religious Gathering in Malaysia after Covid-19 Cases Confirmed." The Straits Times. March 2020. 